\title{
An Amperometric Biosensor Based on Alanine Dehydrogenase for the Determination of Low Level of Ammonium Ion in Water
}

\author{
Tan Ling Ling, ${ }^{1}$ Musa Ahmad, ${ }^{2}$ and Lee Yook Heng' \\ ${ }^{1}$ School of Chemical Sciences and Food Technology, Faculty of Science and Technology, Universiti Kebangsaan Malaysia, \\ Selangor, 43600 Bangi, Malaysia \\ ${ }^{2}$ Chancellor Office, Islamic Science University of Malaysia, Bandar Baru Nilai, Negeri Sembilan, 71800 Nilai, Malaysia \\ Correspondence should be addressed to Lee Yook Heng, leeyookheng@yahoo.co.uk
}

Received 4 May 2011; Accepted 30 June 2011

Academic Editor: Michele Penza

Copyright (๑) 2011 Tan Ling Ling et al. This is an open access article distributed under the Creative Commons Attribution License, which permits unrestricted use, distribution, and reproduction in any medium, provided the original work is properly cited.

\begin{abstract}
An amperometric electrochemical biosensor has been developed for ammonium $\left(\mathrm{NH}_{4}{ }^{+}\right)$ion detection by immobilising alanine dehydrogenase $(\mathrm{AlaDH})$ enzyme in a photocurable methacrylic membrane made up of poly(2-hydroxyethyl methacrylate) (pHEMA) on a screen-printed carbon paste electrode (SPE). The current detected was based on the electrocatalytic oxidation of nicotinamide adenine dinucleotide reduced (NADH) that is proportional to the consumption of $\mathrm{NH}_{4}{ }^{+}$ion whilst enzymatic amination of $\mathrm{AlaDH}$ and pyruvate is taking place. The biosensor was operated amperometrically at a potential of $+0.6 \mathrm{~V}$ and optimum $\mathrm{pH}$ 7. The $\mathrm{NH}_{4}{ }^{+}$biosensor demonstrated linear response to $\mathrm{NH}_{4}{ }^{+}$ion concentration in the range of $0.03-1.02 \mathrm{mg} / \mathrm{L}$ with a limit of detection (LOD) of $8.52 \mu \mathrm{g} / \mathrm{L}$. The proposed method has been successfully applied to the determination of $\mathrm{NH}_{4}{ }^{+}$ ion in river water samples without any pretreatment. The levels of possible interferents in the waters were negligible to cause any interference on the proposed method. The analytical performance of the biosensor was comparable to the colorimetric method using Nesslerisation but with much lower detection limit and linear response range at ppb level.
\end{abstract}

\section{Introduction}

$\mathrm{NH}_{4}{ }^{+}$ion is known as an essential element for plant growth at low concentration in the world's water system. However, high concentration of this species can result from the incomplete degradation of biological waste and sewage by microorganisms, excretion by animals and plants, release of fertilizers, agricultural run-off, and industrial emissions [15]. Wee et al. [6] revealed that the mechanism of $\mathrm{NH}_{4}{ }^{+}$ toxicity in fish might be similar to that in mammals. $\mathrm{NH}_{4}{ }^{+}$ ion also plays an important role as a precursor for aerosol formation [7]. Thus, the development of a sensitive and selective analytical method for $\mathrm{NH}_{4}{ }^{+}$ion is significant.

$\mathrm{NH}_{4}{ }^{+}$ion can be a menace to public health as it can be an indicator of disorder or disease such as kidney disorder, stomach bacterial infection, or liver dysfunction by ingestion of $\mathrm{NH}_{4}{ }^{+}$-contaminated food $[5,8-10]$. A chronically elevated concentration of $\mathrm{NH}_{4}{ }^{+}$ion in blood can severely perturb brain function [11]. At the organismal level, $\mathrm{NH}_{4}{ }^{+}$causes hyperventilation, hyperexcitability, coma, convulsions, and finally death. Determination of $\mathrm{NH}_{4}{ }^{+}$ion in natural water is therefore of a significant interest in environmental biological studies and environmental evaluation of water since it is known to be toxic for aquatic organisms at concentration above $0.025 \mathrm{mg} / \mathrm{L}[4,9,12-14]$.

Due to an increasing environmental awareness and stricter regulations for pollution control, a large number of studies have been demonstrated to determine $\mathrm{NH}_{4}{ }^{+}$ ion in water. These include flow spectrophotometric [15], solvent extraction spectrophotometric [16], UV-VIS spectrophotometric [8], potentiometric [17, 18], flow injection analysis with fluorometric [19], amperometric methods [1, 9], molecular method with ammonia-oxidizing bacteria [2022], continuous colorimetric assays [3,23], and fluorometric $[4,24]$. However, these methods are either time consuming or require elaborate preparation procedures. For instance, $\mathrm{NH}_{4}{ }^{+}$ion determination based on spectrophotometric, fluorometric, and colorimetric methods although simple, economical, and easy for automation, they require pretreatment of the samples to avoid background interferences. The 
most common technique used with optical measurement is the Berhelot's reaction $[3,25]$. But still, there are disadvantages such as slow kinetics, consumption of reagents, and the irreversibility of the reaction itself [4]. Whereas potentiometric involved selective electrode for $\mathrm{NH}_{4}^{+}$ion measurement, suffer interference from alkali metal ions [26, 27].

Enzymatic biosensors have been extensively applied in clinical, food, and environmental areas due to the advantages of fast detection speed, high selectivity, and sensitivity. Enzyme immobilisation onto electrode surfaces is the crucial step in fabricating electrical enzyme biosensors. The procedure used to immobilise enzymes should result in stability, allow diffusion of substrates and products, and ensure an efficient electron transfer [28]. In the present study, amperometric method involving modification of SPE by incorporating the AlaDH enzyme in photoHEMA membrane might offer rather simple, economical, reliable, rapid, sensitive, reproducible analytical procedures and control of the distribution and orientation of the immobilised enzymes. This considerably improved the sensitivity of the analysis when compared with the potentiometric-based procedures. Moreover, this method does not suffer from alkali metal ions (mainly potassium ion) interferences which affect the potentiometric nonactin-based $\mathrm{NH}_{4}{ }^{+}$electrodes. Figure 1 represents the electrode design implying the mechanism of enzymatic reaction by immobilized AlaDH in photoHEMA.

In enzymology, the AlaDH enzyme catalyses the chemical reaction as shown in the following equation (see (1); [29]). AlaDH enzyme catalyses the reductive amination of pyruvate to L-alanine in the presence of cofactor NADH [30]. The enzyme has a fourfold affinity for pyruvate higher than that for L-alanine [31]. During enzymatic redox reaction, AlaDH enzyme consumes $\mathrm{NH}_{4}{ }^{+}$ion for specific amination of pyruvate and $\mathrm{NADH}$ is oxidized to $\mathrm{NAD}^{+}$. The electrochemical oxidation of NADH which occurs at working electrode produces two electrons (see (2); [32]) resulted in current raised proportional to the concentration of analyte $\mathrm{NH}_{4}{ }^{+}$. Thus, the signal was determined indirectly by monitoring the enzymatic consumption of $\mathrm{NADH}$ with amperometric method

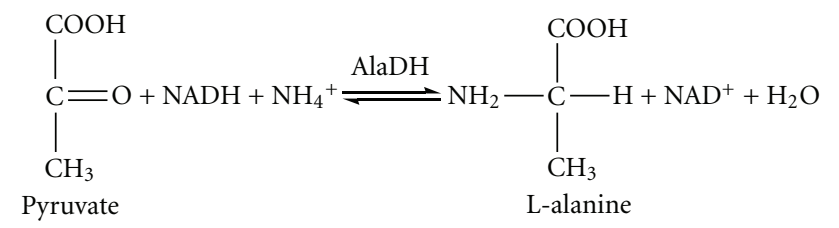

$$
\mathrm{NADH} \longrightarrow \mathrm{NAD}^{+}+\mathrm{H}^{+}+2 \mathrm{e}^{-}
$$

\section{Experimental Section}

2.1. Reagents. All chemicals used were of analytical grade and deionised water was used throughout for solution preparation. Stock solution of $0.0032 \mathrm{mg} / \mu \mathrm{L}$ L-alanine dehydrogenase enzyme (AlaDH, E.C. 1.4.1.1, from Bacillus subtilis) (Sigma) was prepared by mixing an appropriate amount of
AlaDH enzyme solution with $10 \mathrm{mM}$ phosphate buffer $\mathrm{pH}$ 7 in an appendorf tube and stored at $4{ }^{\circ} \mathrm{C}$ [33]. $10 \mathrm{mM} \beta$ nicotinamide adenine dinucleotide, reduced form $(\mathrm{NADH}$, $98 \%$ ) from Sigma was prepared fresh with an ice cool $10 \mathrm{mM}$ phosphate buffer $\mathrm{pH} 7$ and used promptly. $50 \mathrm{mM}$ sodium pyruvate $\left(\mathrm{C}_{3} \mathrm{H}_{3} \mathrm{NaO}_{3}, 99 \%\right)$ (Sigma) stock solution was prepared by dissolving an appropriate amount of pyruvate salt in deionised water. $10 \mathrm{mM}$ phosphate buffer $\mathrm{pH} 7$ was prepared by adding $10 \mathrm{mM}$ dipotassium hydrogen phosphate $\left(\mathrm{K}_{2} \mathrm{HPO}_{4}, 98 \%\right)$ (Fluka) to $10 \mathrm{mM}$ potassium dihydrogen phosphate $\left(\mathrm{KH}_{2} \mathrm{PO}_{4}, 99.5 \%\right)$ (Fluka) and adjusted to the required $\mathrm{pH}$ value [33].

A standard stock ammonia solution was prepared by dissolving the required amount of concentrated ammonia solution $\left(\mathrm{NH}_{3}, 25 \%\right)$ (MERCK) in the deionised water. The ammonia solution used has been standardised with Nessler method using ammonium chloride $\left(\mathrm{NH}_{4} \mathrm{Cl}, 99.5 \%\right)$ salt. A homogeneous stock solution of monomer 2-hydroxyethyl methacrylate $\left(\mathrm{C}\left(\mathrm{CH}_{3}\right) \mathrm{COOCH}_{2} \mathrm{CH}_{2} \mathrm{OH}, 97 \%\right)$ (Aldrich) was prepared by mixing appropriate amounts of monomer HEMA and initiator 2,2-dimethoxy-2-phenylacetophenone (DMPP) $\left(\mathrm{C}_{16} \mathrm{H}_{16} \mathrm{O}_{3}, 98 \%\right)$ (Fluka) in a vial and wrapped with aluminium foil. The mixture was then stirred gently for a few minutes and stored at $4^{\circ} \mathrm{C}$.

2.2. Instrumentation. Chronoamperometric measurements were performed with an AUTOLAB PG12 (AUT 71681) Potentiostat/Galvanostat. Screen-printed carbon paste electrode (SPE) designed by Universiti Kebangsaan Malaysia and manufactured by Scrint Print Co was coated with immobilised $\mathrm{AlaDH}$ enzyme membrane and used as the working electrode. $\mathrm{Ag} / \mathrm{AgCl}$ and glassy carbon electrode were used as the reference and auxiliary electrodes, respectively. A magnetic stirrer was used to stir the electrolyte during the amperometric measurements. Measurements of $\mathrm{pH}$ were made with $\mathrm{pH}$-meter (MeterLab PHM 210) using a combined glass electrode. AlaDH enzyme-containing pHEMA membrane was prepared by UV-initiated photopolymerisation with an UV-exposure unit (RS Components 196-5251).

2.3. Construction of Biosensor. To fabricate the AlaDH enzyme electrode, a mixture of monomer HEMA and AlaDH enzyme of $5 \mu \mathrm{L}$ was prepared in the ratio of $1: 1$ with the enzyme concentration of 0.6 units. The mixture was then deposited onto the SPE and exposed to long-wave ultraviolet radiation for 500 seconds with an extensive nitrogen $\left(\mathrm{N}_{2}\right)$ gas purging.

2.4. Optimisation of Biosensor Responses. Quantitative determination of $\mathrm{NH}_{4}{ }^{+}$ion was performed by chronoamperometry using AlaDH enzyme electrode. The capability of the electrochemical biosensor was characterised in terms of optimal conditions, dynamic range, detection limit, reproducibility and repeatability studies, hydrodynamic study, and shelf life study. The studies were carried out at room temperature and $5 \mathrm{~mL}$ of $10 \mathrm{mM}$ phosphate buffer $\mathrm{pH} 7$ was used as the carrier solution under constant stirring condition $(100 \mathrm{rpm})$. The substrates mixture containing $\mathrm{NH}_{4}{ }^{+}$ion, 


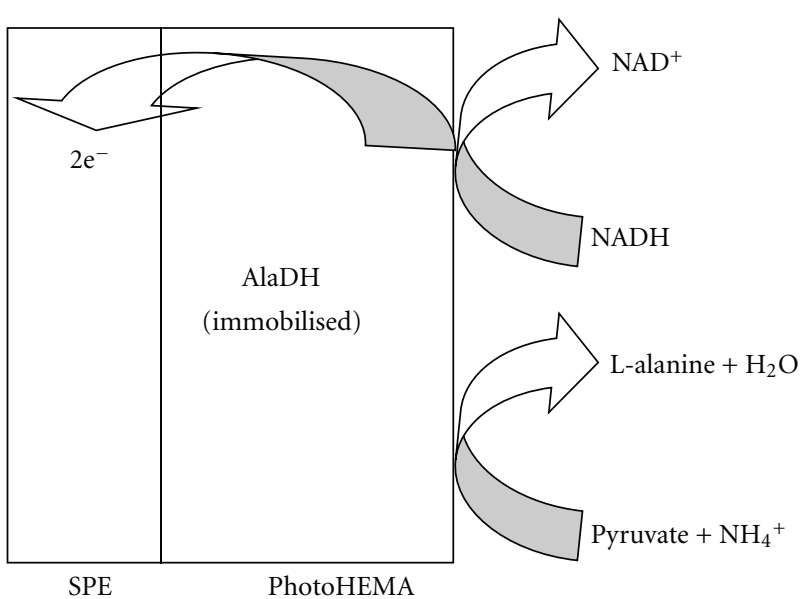

FIGURE 1: The mechanism of enzymatic reaction involved in the developed $\mathrm{NH}_{4}{ }^{+}$biosensor.

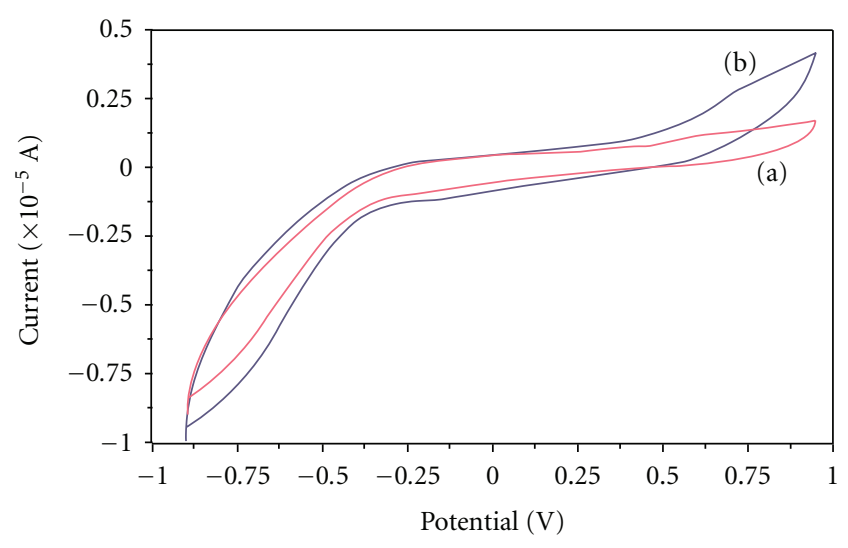

Figure 2: Cyclic voltammograms of AlaDH electrode in the absence (a) and presence (b) of $1.70 \mathrm{mg} / \mathrm{L} \mathrm{NH}_{4}{ }^{+}$ion. The experiment was conducted in the presence of $0.3 \mathrm{mM}$ pyruvate and $\mathrm{NADH}$ at $\mathrm{pH} 7$ with a scan rate of $0.02 \mathrm{~V} / \mathrm{s}$ versus $\mathrm{Ag} / \mathrm{AgCl}$ electrode.

pyruvate, and NADH was added into the amperometric cell after a stable baseline obtained. The measurements taken were expressed as the current difference, defined as the stable current obtained after electrochemical reaction minus that of the stable baseline current. The measurements were carried out in triplicates.

The amperometric response of the $\mathrm{AlaDH}$ enzyme electrode was first studied with cyclic voltammetry between $-1.00-1.00 \mathrm{~V}$ versus $\mathrm{Ag} / \mathrm{AgCl}$ at a scan rate of $0.02 \mathrm{~V} / \mathrm{s}$. Next, the hydrodynamic study was conducted by changing the applied potential in the range of $0.45-0.80 \mathrm{~V}$ versus $\mathrm{Ag} / \mathrm{AgCl}$. The effect of $\mathrm{pH}$ against biosensor response was studied by varying the $\mathrm{pH}$ of the carrier solution $(10 \mathrm{mM}$ phosphate buffer) in the range of $\mathrm{pH}$ 5.8-8.0. Whereas the effect of enzyme loading was carried out by changing the enzyme loading in the pHEMA membrane in the range of 0.0900 0.8250 units.

To prepare enzyme electrodes with different membrane thicknesses, different mixtures of monomer HEMA and

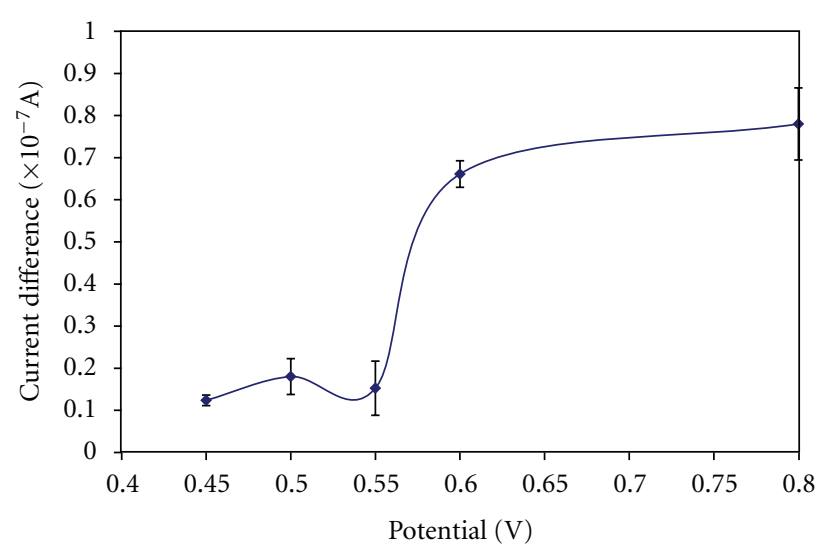

Figure 3: The dependence of the AlaDH electrode response on the applied electrode potential. The solution containing $1.70 \mathrm{mg} / \mathrm{L}$ $\mathrm{NH}_{4}{ }^{+}$ion and $0.3 \mathrm{mM}$ pyruvate and NADH at $\mathrm{pH} 7(n=3)$.

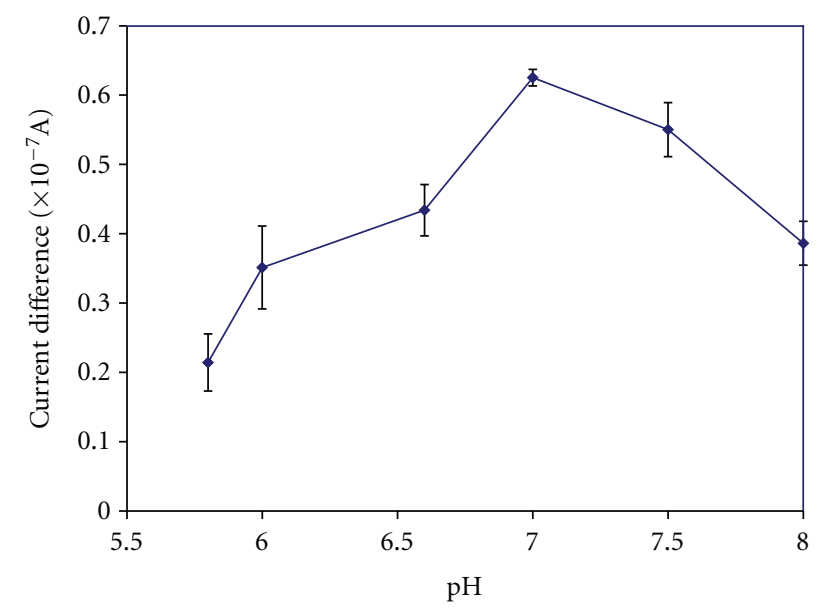

Figure 4: The $\mathrm{pH}$ profiles of AlaDH electrode in solution containing $1.70 \mathrm{mg} / \mathrm{L} \mathrm{NH}_{4}{ }^{+}$ion $(n=3)$.

AlaDH enzyme $(0.5-6 \mu \mathrm{L})$ were prepared in the ratio of $1: 1$ with the constant enzyme loading of 0.6 units. The thicknesses of the membranes were then determined using digital vernier caliper with $0.01 \mathrm{~mm}$ precision.

To determine the influence of temperature on biosensor response, the temperature was varied from $10^{\circ} \mathrm{C}$ to $50^{\circ} \mathrm{C}$. For the optimisation of respective $\mathrm{NADH}$ and pyruvate concentrations, phosphate buffer $\mathrm{pH} 7$ with various concentrations of pyruvate $(0.001-0.05 \mathrm{mM})$ and NADH $(0.02-0.3 \mathrm{mM})$ was used. After that, the effect on biosensor performance was investigated against different $\mathrm{NH}_{4}{ }^{+}$ion concentration $(0.03-$ $3.41 \mathrm{mg} / \mathrm{L}$ ) and the concentration of pyruvate and NADH were kept constant.

The reproducibility of the biosensor was studied by measuring the response of different SPE to the same $\mathrm{NH}_{4}{ }^{+}$ ion concentration at $0.68 \mathrm{mg} / \mathrm{L}$. Whereas the repeatability of the biosensor was studied using the same SPE with the same $\mathrm{NH}_{4}{ }^{+}$ion concentration at $0.68 \mathrm{mg} / \mathrm{L}$ and the current difference signals were taken five times for each SPE. Shelf life study of AlaDH enzyme-based electrode was studied 


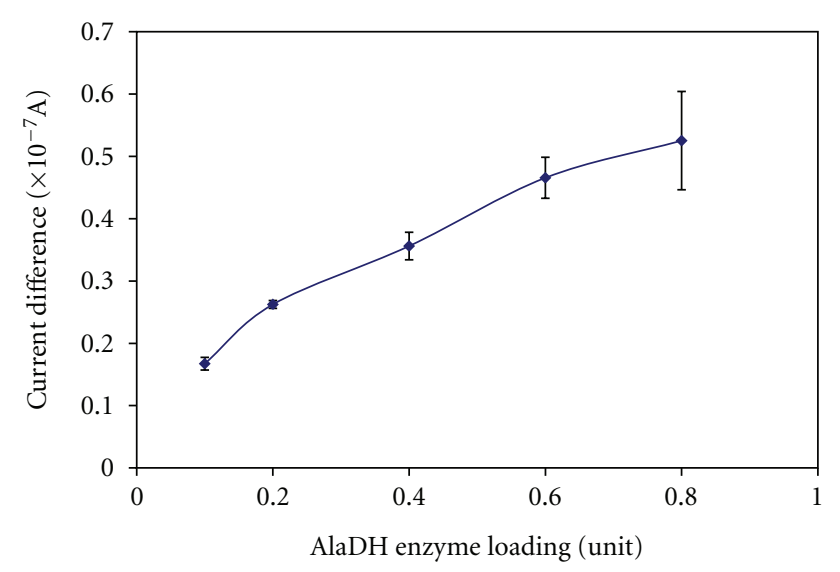

Figure 5: Effect of enzyme loading against $\mathrm{AlaDH}$ electrode response in solution containing $1.70 \mathrm{mg} / \mathrm{L} \mathrm{NH}_{4}{ }^{+}$ion at $\mathrm{pH} 7(n=$ $3)$.

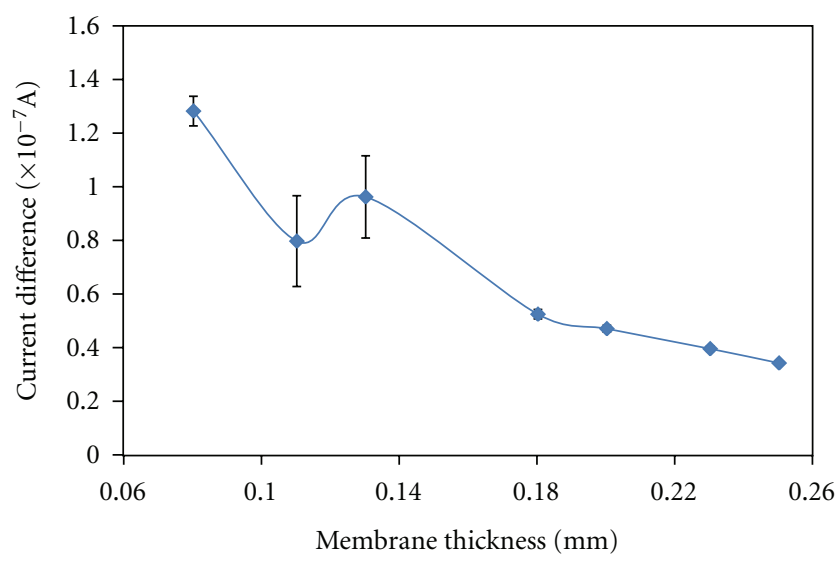

Figure 6: Effect of membrane thickness against AlaDH electrode response in solution containing $1.70 \mathrm{mg} / \mathrm{L} \mathrm{NH}_{4}{ }^{+}$ion at $\mathrm{pH} 7(n=$ $3)$.

measuring $1.53 \mathrm{mg} / \mathrm{L} \mathrm{NH}_{4}{ }^{+}$ion using the same electrode at a time interval of 2 days until a plateau response obtained.

To assess the effect of alkali $\left(\mathrm{Na}^{+}, \mathrm{K}^{+}\right)$, alkaline earth $\left(\mathrm{Mg}^{2+}, \mathrm{Ca}^{2+}\right)$, heavy metal $\left(\mathrm{Fe}^{3+}\right)$, amines (methylamine, ethylamine), and sulphate ion $\left(\mathrm{SO}_{4}^{2-}\right)$ interferences, twocomponent mixtures of $\mathrm{NH}_{4}{ }^{+}$ion with interferent in different molar ratio of interferent against $\mathrm{NH}_{4}{ }^{+}$ion in the range of 10-5000 were analysed by amperometric method. The current differences obtained for interferent $/ \mathrm{NH}_{4}{ }^{+}$ion mixtures were compared with those for pure, single component solution $\left(0.68 \mathrm{mg} / \mathrm{L} \mathrm{NH}_{4}{ }^{+}\right.$ion $)$using $t$-test.

Finally, the constructed biosensors were applied for recovery test using various standard concentrations of $\mathrm{NH}_{4}{ }^{+}$ ion and real sample analysis of river water. The results were validated by using established procedure of Nessler method.

\section{Results and Discussions}

Figure 2 shows the typical cyclic voltammograms demonstrating the electrocatalytic activity of AlaDH enzyme electrode in aqueous solutions containing $10 \mathrm{mM}$ phosphate

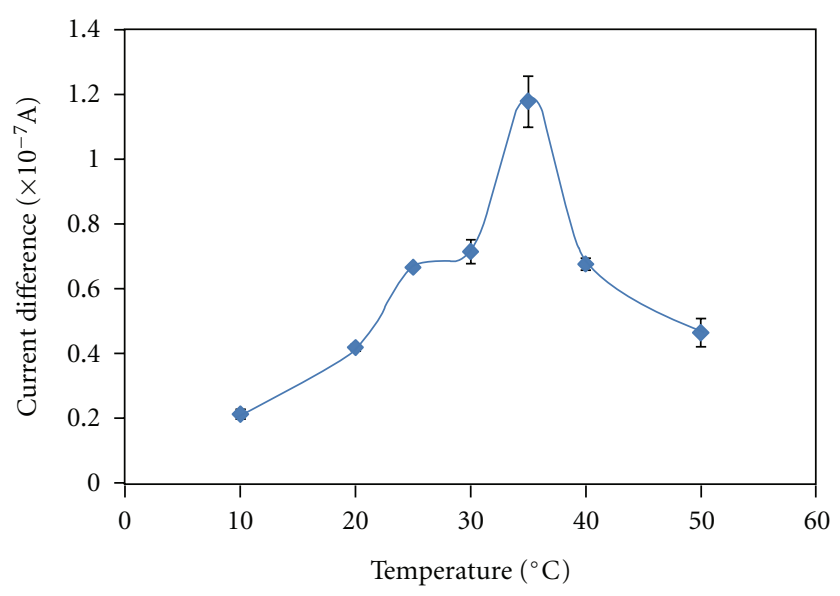

Figure 7: Temperature profile of $\mathrm{AlaDH}$ electrode in solution containing $1.70 \mathrm{mg} / \mathrm{L} \mathrm{NH}_{4}{ }^{+}$ion at $\mathrm{pH} 7(n=3)$.

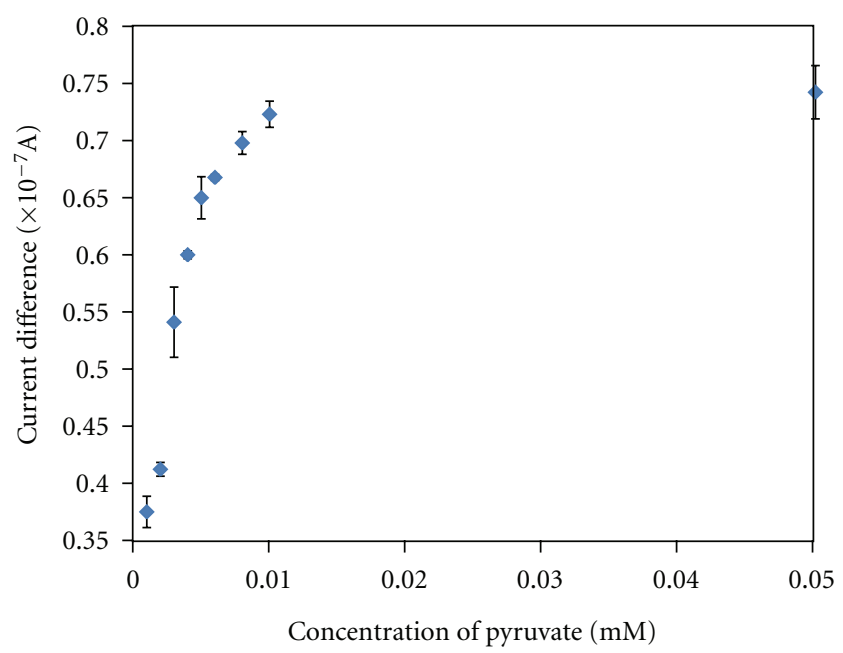

FIGURE 8: Determination of optimum pyruvate concentration in electrolyte solution containing $0.3 \mathrm{mM} \mathrm{NADH}$ and $1.70 \mathrm{mg} / \mathrm{L} \mathrm{NH}_{4}{ }^{+}$ ion at $\mathrm{pH} 7(n=3)$.

buffer $\mathrm{pH} 7$ in the absence and presence of substrates $1.70 \mathrm{mg} / \mathrm{L} \mathrm{NH}_{4}{ }^{+}$ion. The experiment was conducted in the presence of $0.3 \mathrm{mM}$ pyruvate and $\mathrm{NADH}$ with a scan rate of $0.02 \mathrm{~V} / \mathrm{s}$ versus $\mathrm{Ag} / \mathrm{AgCl}$ electrode between potential range of $-1.00-1.00 \mathrm{~V}$. The addition of $\mathrm{NH}_{4}{ }^{+}$ion gave rise to a higher current in the potential range of $0.4-0.9 \mathrm{~V}$ due to the electrocatalytic oxidation of NADH during enzymatic conversion of pyruvate to $\mathrm{L}$-alanine in the presence of $\mathrm{NH}_{4}{ }^{+}$ ion whilst the enzyme redox reaction. Hence, it seemed possible to quantify $\mathrm{NH}_{4}{ }^{+}$ion concentration indirectly by measuring the increased current of NADH oxidation.

In order to choose the best potential to be applied for amperometric determination of $\mathrm{NH}_{4}{ }^{+}$ion, a hydrodynamic voltammogram was recorded in the potential range of $0.45-$ $0.80 \mathrm{~V}$ versus $\mathrm{Ag} / \mathrm{AgCl}$ electrode (Figure 3). At applied potential of $+0.6 \mathrm{~V}$, the current reached plateau and therefore, this potential was adopted for further studies. Bertocchi and Compagnone [32] have reported the same result trend 


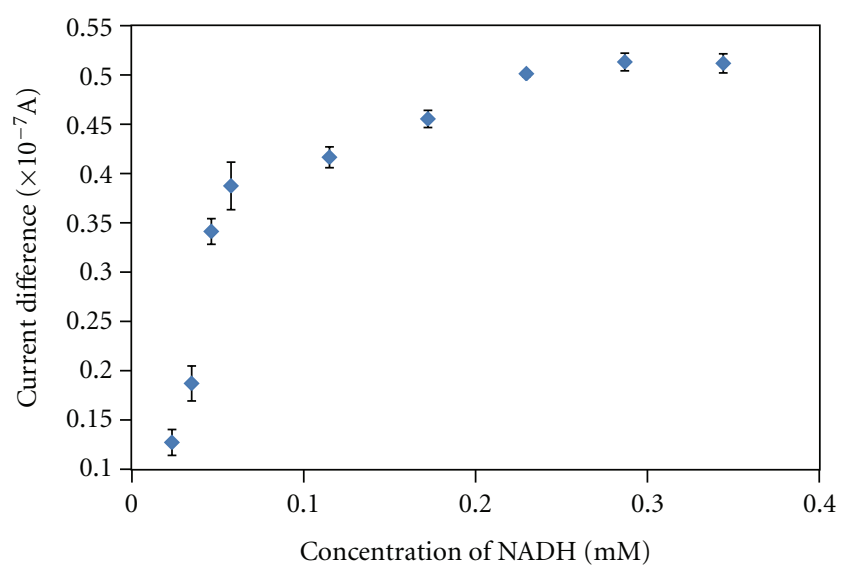

Figure 9: Determination of optimum NADH concentration in electrolyte solution containing $0.01 \mathrm{mM}$ pyruvate and $1.70 \mathrm{mg} / \mathrm{L}$ $\mathrm{NH}_{4}{ }^{+}$ion at $\mathrm{pH} 7(n=3)$.

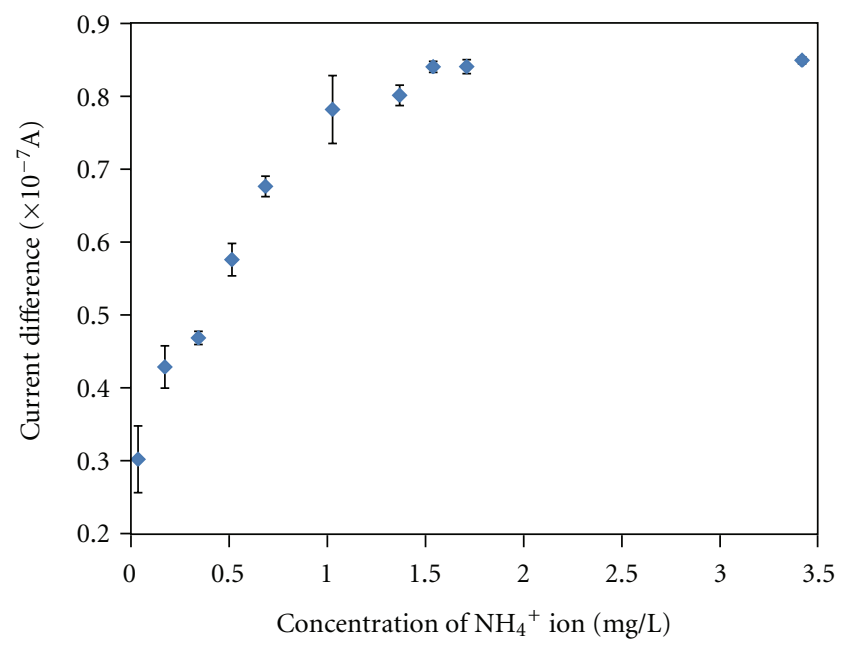

Figure 10: The response curve of the AlaDH electrode towards different $\mathrm{NH}_{4}{ }^{+}$ion concentration in the range of $0.03-3.41 \mathrm{mg} / \mathrm{L}$ at $\mathrm{pH} 7(n=3)$.

in amperometric $\mathrm{NH}_{4}{ }^{+}$ion determination using glutamate dehydrogenase (GLDH) enzyme-based probe.

Enzymes are amphoteric molecules containing a large number of acid and basic groups, mainly situated on their surface. The charges on these groups will vary, according to their $\mathrm{pH}$ environment. This will affect the total net charge of the enzymes and the distribution of charge on their exterior surfaces, in addition to the reactivity of the catalytically active groups. These effects are especially important in the neighbourhood of the active sites. Taken together, the changes in charges with $\mathrm{pH}$ affect the activity, structural stability, and solubility of the enzyme. The isoelectric point of $\mathrm{AlaDH}$ is at $\mathrm{pH} 6.7$, at which the enzyme generally has minimum solubility in aqueous solutions and the net charge on the molecule is zero [34]. In a similar manner to the effect on enzymes, the charge and charge distribution on the substrate, product and coenzymes will also be affected by $\mathrm{pH}$
TABLE 1: Thicknesses of pHEMA membrane containing 0.6 units of AlaDH enzyme determined using digital vernier caliper $(n=3)$.

\begin{tabular}{lc}
\hline $\begin{array}{l}\text { Total volume of AlaDH and } \\
\text { monomer HEMA mixture in } \\
\text { volume ratio of } 1: 1(\mu \mathrm{L})\end{array}$ & $\begin{array}{r}\text { Thickness of AlaDH-containing } \\
\text { pHEMA membrane }(\mathrm{mm})\end{array}$ \\
\hline 0.5 & $0.08 \pm(0.02)$ \\
1.0 & $0.11 \pm(0.02)$ \\
2.0 & $0.13 \pm(0.02)$ \\
3.0 & $0.18 \pm(0.02)$ \\
4.0 & $0.20 \pm(0.03)$ \\
5.0 & $0.23 \pm(0.01)$ \\
6.0 & $0.25 \pm(0.01)$ \\
\hline
\end{tabular}

changes [35]. In the present work, the maximum sensitivity of the immobilised AlaDH was observed at $\mathrm{pH} 7.0$ (Figure 4). Schroder et al. [31] has also reported that the $\mathrm{pH}$ optimum of AlaDH for both the deamination and amination reactions was $\sim \mathrm{pH} 7.0$.

As observed in Figure 5, the response increased with an increase in the $\mathrm{AlaDH}$ enzyme loading of the membrane. It shows that the enzyme loading of 0.6 units was sufficient to obtain high enough response in this system. Kwan et al. [36] has used the same amount of AlaDH enzyme to be entrapped by a poly (carbamoyl) sulfonate (PCS) hydrogel on a Teflon membrane for amperometric determination of alanine. Table 1 shows the thicknesses of pHEMA membranes containing 0.6 units of $\mathrm{AlaDH}$ enzyme determined using digital vernier caliper with $0.01 \mathrm{~mm}$ precision.

The effect of membrane thickness against AlaDH electrode response is depicted in Figure 6. The optimum thickness of AlaDH enzyme-containing photoHEMA membrane was found to be $0.23 \mathrm{~mm}$ from $5 \mu \mathrm{L}$ matrix due to the lowest standard deviation to make the same electrode each time and gave consistent signal against same substrates concentration. Membrane thickness of $0.25 \mathrm{~mm}$ was not chosen for enzyme immobilisation in the subsequent works as the thick pHEMA membrane possessed more cross-link structures, which could prevent or slow the substrates from penetrating the membrane to effect the enzymatic reaction, and thus result in lower response.

Temperature is another parameter which must be taken into consideration for biosensor performance. Figure 7 shows the profile of $\mathrm{NH}_{4}{ }^{+}$biosensor response against temperature. The response increases with temperature and the optimum temperature is observed at $35^{\circ} \mathrm{C}$. This increased stability at higher temperature might be explained by the polymer matrix acting as a kind of scaffold thus preventing denaturation due to extensive conformational changes [37]. Anyhow, high working temperature $\left(30^{\circ} \mathrm{C}\right)$ cannot promote the sensor performance effectively due to the reduction of the availability of dissolved oxygen in the buffer for the enzymatic reactions and the promotions of slow denaturations of enzyme [36]. When the temperature shifted to $55^{\circ} \mathrm{C}$, $\mathrm{AlaDH}$ enzyme lost about $70 \%$ of its original activity [29]. In the present work, $25^{\circ} \mathrm{C}$ was selected as working temperature 


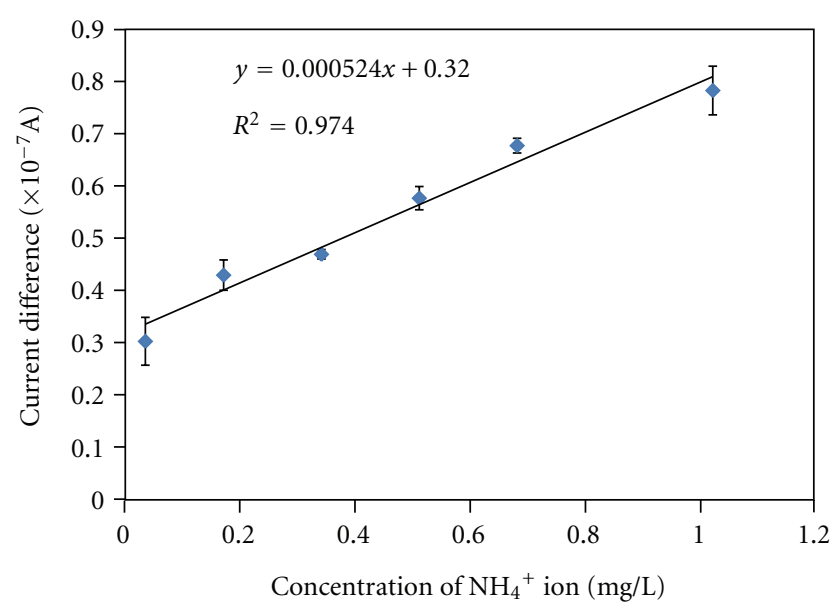

FIGURE 11: Linear response produced by the AlaDH electrode in the $\mathrm{NH}_{4}{ }^{+}$ion concentration range of $0.03-1.02 \mathrm{mg} / \mathrm{L}$ at $\mathrm{pH} 7(n=3)$.

TABle 2: Data for shelf life study of AlaDH enzyme-based electrode tested in solution containing $1.53 \mathrm{mg} / \mathrm{L} \mathrm{NH}_{4}{ }^{+}$ion, $0.25 \mathrm{mM} \mathrm{NADH}$, and $0.01 \mathrm{mM}$ pyruvate at $\mathrm{pH} 7$ over a period of 11 days $(n=3)$.

\begin{tabular}{lclc}
\hline Time (day) & $\begin{array}{c}\text { Current Difference } \\
\left(\times 10^{-7} \mathrm{~A}\right)\end{array}$ & $\begin{array}{c}\text { Standard } \\
\text { deviation }\end{array}$ & $\begin{array}{c}\text { Relative } \\
\text { response } \\
(\%)\end{array}$ \\
\hline 1 & 0.828 & 0.023 & 100.0 \\
3 & 0.332 & 0.076 & 40.1 \\
5 & 0.243 & 0.049 & 29.3 \\
7 & 0.223 & 0.055 & 26.9 \\
9 & 0.222 & 0.081 & 26.8 \\
11 & 0.205 & 0.131 & 24.7 \\
\hline
\end{tabular}

for all subsequent experiments since the sensitivity of the biosensors was sufficiently good for further studies.

To improve the performance of AlaDH electrode, various pyruvate and NADH concentrations were investigated. For the optimisation of respective pyruvate and NADH concentrations, the biosensor response to $1.70 \mathrm{mg} / \mathrm{L} \mathrm{NH}_{4}{ }^{+}$ion with various pyruvate and $\mathrm{NADH}$ concentrations is presented in Figures 8 and 9. The response increases with increasing pyruvate and $\mathrm{NADH}$ concentrations and became saturated at concentrations of $0.01 \mathrm{mM}$ pyruvate and $0.25 \mathrm{mM} \mathrm{NADH}$, respectively.

The response curve of $\mathrm{NH}_{4}{ }^{+}$ion concentration determined using the AlaDH enzyme electrode is shown in Figure 10. A plateau region is achieved when the concentration of $\mathrm{NH}_{4}{ }^{+}$ion is higher than $1.53 \mathrm{mg} / \mathrm{L}$.

The plot of $\mathrm{NH}_{4}{ }^{+}$ion concentration against current difference was linear in the $\mathrm{NH}_{4}{ }^{+}$ion concentration range of $0.03-1.02 \mathrm{mg} / \mathrm{L}$ (Figure 11). The linear part of plot can be described by the regression equation $y=8.135 x-0.320$ with correlation coefficient, $R^{2}$ of 0.974 . The LOD of $\mathrm{NH}_{4}{ }^{+}$ion, defined here as the concentration equivalent to a signal of blank plus three times the standard deviation of the blank [38] was found to be $8.52 \mu \mathrm{g} / \mathrm{L}$.

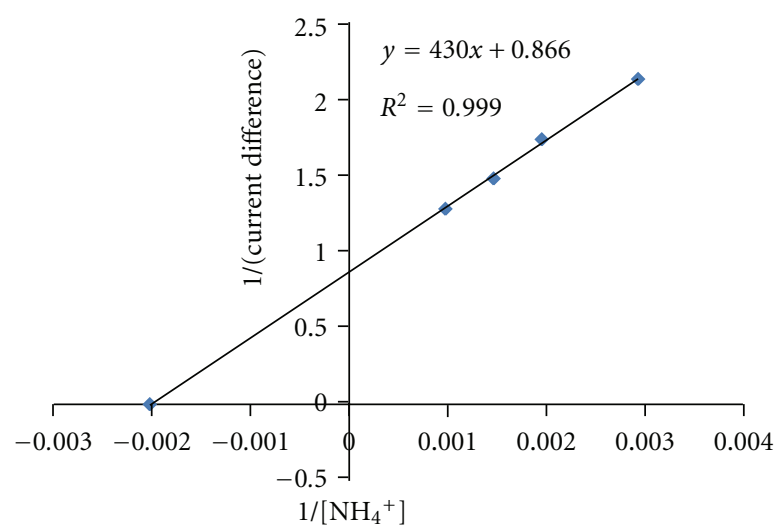

Figure 12: Lineweaver-Burk plots of the immobilised AlaDH enzyme in pHEMA membrane.

Kinetic parameters of the enzymatic reaction can be estimated by the direct linear method of the LineweaverBurk plot from the experimental data [39]. The apparent Michaelis-Menten constant $\left(K_{m}\right)$ estimated from the Lineweaver-Burk plot was $0.029 \mathrm{mM}$ for $\mathrm{NH}_{4}{ }^{+}$ion (Figure 12).

Few methods for the amperometric determination of $\mathrm{NH}_{4}{ }^{+}$ion have been developed and reported. The amperometric $\mathrm{NH}_{4}{ }^{+}$electrode developed by Abass et al. [1] involved the use of SPE modified with Meldola's Blue over which is fixed a polycarbonate membrane. This sensor detect $\mathrm{NH}_{4}{ }^{+}$ion indirectly by measuring the rate of decrease in current that was found to be dependent on the concentration of GLDH enzyme, 2-oxoglutarate, and NADH. The sensitivity of ammonium biosensor reported by Kwan et al. [9] using a immobilization matrix poly(carbamoyl) sulfonate hydrogel containing a bienzyme system is lower when compared to the biosensor reported in this work (based on immobilised AlaDH in photoHEMA membrane) but the biosensor reported here demonstrated wider linear range of $0.029-4.26 \mathrm{mg} / \mathrm{L}$. Another method for fluorometric $\mathrm{NH}_{4}{ }^{+}$ion determination by ion chromatography (IC) using postcolumn derivatisation with $o$-phthaldialdehyde (OPA) under high concentrations of sodium and amino acids matrices has been developed by Kuo et al. [24] and showed good sensitivity with linear range of $0.85-85.17 \mu \mathrm{g} / \mathrm{L}$ and LOD of $0.85 \mu \mathrm{g} / \mathrm{L}$. To remove amino acid interference, the postcolumn derivatization based on the reaction of ammonia with OPA and sulfite was applied. Thus, the ammonium biosensor developed in this work has advantage in terms of simple fabrication and application when compared to those reported so far and yet provided performance that is comparable or even better than those using other immobilization matrices.

The reproducibility and repeatability of the biosensor were evaluated at $0.68 \mathrm{mg} / \mathrm{L} \mathrm{NH}_{4}{ }^{+}$ion. The current difference measurement obtained using the same SPE yielded satisfactory repeatability RSD values in the range of 6.4$11.2 \%(n=5)$. Whereas the measurement obtained using the different SPE gave very promising RSD values of $1.4-4.5 \%$ 
TABLE 3: The interference effect of $\mathrm{Na}^{+}, \mathrm{K}^{+}, \mathrm{Mg}^{2+}, \mathrm{Ca}^{2+}, \mathrm{Fe}^{3+}, \mathrm{SO}_{4}^{2-}, \mathrm{CH}_{3} \mathrm{NH}_{2}$, and $\mathrm{C}_{2} \mathrm{H}_{5} \mathrm{NH}_{2}$ at different molar ratio of interferent to $\mathrm{NH}_{4}^{+}$ ion on the determination of $0.68 \mathrm{mg} / \mathrm{L} \mathrm{NH}_{4}{ }^{+}$ion using AlaDH electrode at $\mathrm{pH} 7(n=3)$.

\begin{tabular}{|c|c|c|c|c|c|}
\hline \multirow{2}{*}{ Interferent } & \multicolumn{5}{|c|}{ Current difference $\left(\times 10^{-7} \mathrm{~A}\right)$ at different molar ratios of interferent: $\mathrm{NH}_{4}{ }^{+}$ion } \\
\hline & $0: 1$ & $10: 1$ & $100: 1$ & $1000: 1$ & $5000: 1$ \\
\hline $\mathrm{Na}^{+}$ & $0.560 \pm 0.025$ & $0.558 \pm 0.033$ & $0.589 \pm 0.027$ & $0.531 \pm 0.012$ & $0.313 \pm 0.083^{*}$ \\
\hline $\mathrm{K}^{+}$ & $0.560 \pm 0.025$ & $0.522 \pm 0.036$ & $0.164 \pm 0.047^{*}$ & & \\
\hline $\mathrm{Mg}^{2+}$ & $0.560 \pm 0.025$ & $0.567 \pm 0.006$ & $0.535 \pm 0.017$ & $0.527 \pm 0.033$ & $0.187 \pm 0.077^{*}$ \\
\hline $\mathrm{Ca}^{2+}$ & $0.560 \pm 0.025$ & $0.556 \pm 0.043$ & $0.449 \pm 0.040^{*}$ & $0.291 \pm 0.066$ & \\
\hline $\mathrm{Fe}^{3+}$ & $0.560 \pm 0.025$ & $0.616 \pm 0.024$ & $0.173 \pm 0.017^{*}$ & & \\
\hline $\mathrm{SO}_{4}^{2-}$ & $0.560 \pm 0.025$ & $0.603 \pm 0.032$ & $0.260 \pm 0.165^{*}$ & & \\
\hline $\mathrm{CH}_{3} \mathrm{NH}_{2}$ & $0.560 \pm 0.025$ & $0.626 \pm 0.014^{*}$ & $0.893 \pm 0.037$ & & \\
\hline $\mathrm{C}_{2} \mathrm{H}_{5} \mathrm{NH}_{2}$ & $0.560 \pm 0.025$ & $0.760 \pm 0.009^{*}$ & $0.806 \pm 0.012$ & & \\
\hline
\end{tabular}

${ }^{*} t$ value $>t$ critical value at $95 \%$ confident level with 4 degrees of freedom.

$(n=5)$ (Figure 13). These RSD were low enough to consider that the membranes were reproducible using the proposed method in the present work.

The shelf life of AlaDH enzyme-based electrode was tested by measuring $1.53 \mathrm{mg} / \mathrm{L} \mathrm{NH}_{4}{ }^{+}$ion at a time interval of 2 days. Once measurements have been carried out, the enzyme electrode was stored at $4^{\circ} \mathrm{C}$ in a refrigerator. After 2-day storage period, the biosensor sensitivity decreased faster, reaching value of approximately $40.1 \%$ of the initial sensitivity and continuously to $29.3 \%$ at day 5 and no significant current differences were observed until 11-day storage period (Figure 14). Data for shelf life study of AlaDH enzyme-based electrode is given .5ptin Table 2.

An amperometric biosensor employing AlaDH enzyme has been developed by Kwan et al. [36] for the determination of alanine. This method had an operational stability of 2 days. However, the method has some problems due to other combination salicylate hydroxylase and pyruvate oxidase enzymes which regulate the buffer $\mathrm{pH}$ of the measuring solution.

In the present work, it was observed that alkali, alkaline earth, heavy metal, and $\mathrm{SO}_{4}^{2-}$ ions did not significantly interfere with the quantitative determination $\mathrm{NH}_{4}{ }^{+}$ion concentrations at low level (Table 3 ). The typical molar ratio of interferent over $\mathrm{NH}_{4}^{+}$ion in natural water is low. So, the existence of interferent ions in concentration higher than $\mathrm{NH}_{4}{ }^{+}$ion in water is not possible. However, the biosensor response reduced significantly at high molar ratio of interferent over $\mathrm{NH}_{4}{ }^{+}$ion with the obtained $t$ value higher than $t$ critical value at $95 \%$ confident level. This is because the presence of high concentration of ions had increased the ionic strength of the medium and further decreased the enzyme activity. The ionic strength of the solution is an important parameter affecting enzyme activity. This is especially noticeable where catalysis depends on the movement of charged molecules relative to each other. Thus both the binding of charged substrates to enzymes and the movement of charged groups within the catalytic "active" site will be influenced by the ionic composition of the medium [34].

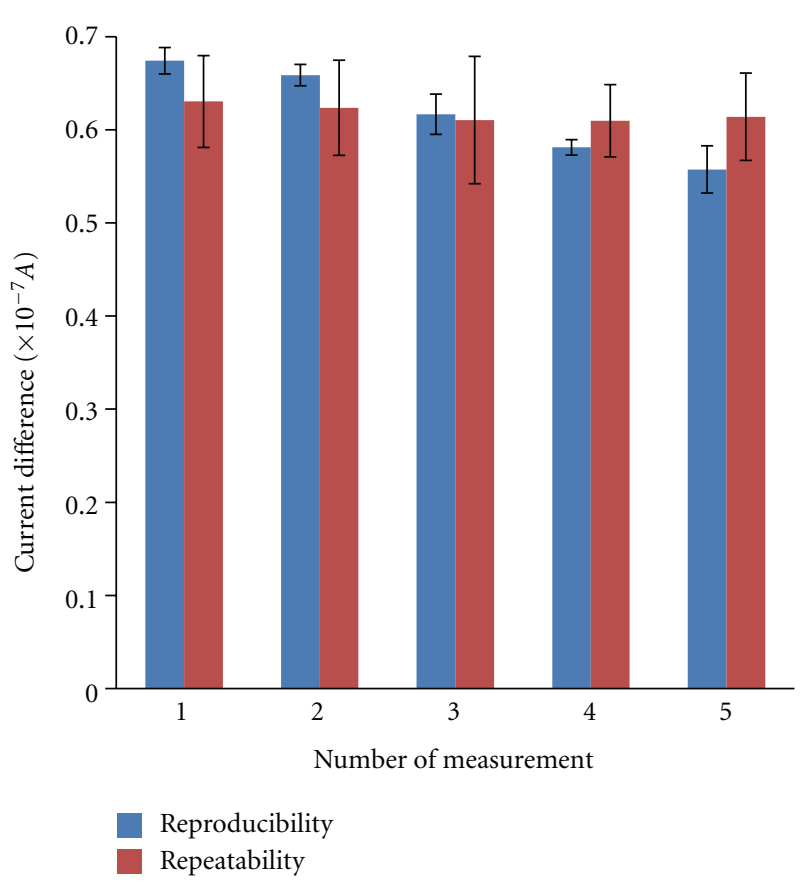

FIGURE 13: The reproducibility and repeatability of AlaDH enzyme electrodes exposed to $0.68 \mathrm{mg} / \mathrm{L} \mathrm{NH}_{4}{ }^{+}$ion at $\mathrm{pH} 7(n=5)$.

The enzyme was found can be stabilised by $\mathrm{K}^{+}$ion, but the degree of stabilisation was lower than by $\mathrm{Na}^{+}$ion. It could be speculated that the stabilisation depends on the hydration effect by these alkali metal ion. However, the hydration potentials of the ions are in the order of Hofmeister's series: $\mathrm{Na}^{+}>\mathrm{K}^{+}[29]$. This is consistent with the order of the interference effect observed: $\mathrm{K}^{+}>\mathrm{Na}^{+} . \mathrm{Fe}^{3+}$ and $\mathrm{Ca}^{2+}$ ions interfered significantly at molar ratio of interferent over $\mathrm{NH}_{4}{ }^{+}$ion of 100 due to the formation of the insoluble precipitation of $\mathrm{Fe}(\mathrm{OH})_{3}$ and $\mathrm{Ca}(\mathrm{OH})_{2}[40,41]$ and has lowered the biosensor reproducibility.

Determination of $\mathrm{NH}_{4}{ }^{+}$ion by amperometric method can also affected by amines, particularly methylamine 


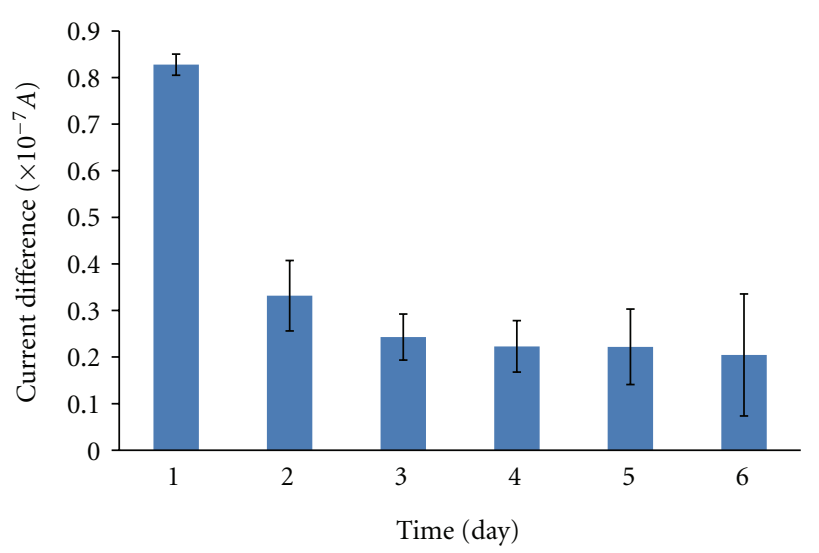

Figure 14: The result on the shelf life study of the AlaDH electrode tested in solution containing $1.53 \mathrm{mg} / \mathrm{L} \mathrm{NH}_{4}{ }^{+}$ion, $0.25 \mathrm{mM} \mathrm{NADH}$ and $0.01 \mathrm{mM}$ pyruvate at $\mathrm{pH} 7$ over a period of 11 days $(n=3)$.

TABLE 4: Performance of AlaDH electrode response against different river water samples with appropriate dilution $(n=3)$.

\begin{tabular}{lccc}
\hline Sample & $\begin{array}{c}\text { Spiked } \mathrm{NH}_{4}{ }^{+} \text {ion } \\
\text { concentration } \\
(\mathrm{mg} / \mathrm{L})\end{array}$ & $\begin{array}{c}\text { Obtained } \mathrm{NH}_{4}{ }^{+} \\
\text {ion concentration } \\
(\mathrm{mg} / \mathrm{L})\end{array}$ & $\begin{array}{c}\text { Recovery } \\
(\%)\end{array}$ \\
\hline Sample 1 & 0.17 & $0.20 \pm 0.06$ & $119.2 \pm 35.2$ \\
Sample 2 & 0.34 & $0.26 \pm 0.14$ & $76.2 \pm 41.1$ \\
Sample 3 & 0.51 & $0.47 \pm 0.04$ & $91.9 \pm 7.8$ \\
Sample 4 & 0.68 & $0.72 \pm 0.06$ & $105.1 \pm 8.8$ \\
Sample 5 & 1.02 & $0.78 \pm 0.17$ & $76.7 \pm 16.6$ \\
\hline
\end{tabular}

$\left(\mathrm{CH}_{3} \mathrm{NH}_{2}\right)$ and ethylamine $\left(\mathrm{C}_{2} \mathrm{H}_{5} \mathrm{NH}_{2}\right)$ which exhibit similar physicochemical properties to $\mathrm{NH}_{4}{ }^{+}$ion. However, amine interferences were unexpected in natural waters due to their low content, usually at least 100 times lower than $\mathrm{NH}_{4}{ }^{+}$ion [23].

The performance of $\mathrm{NH}_{4}{ }^{+}$biosensor has been evaluated using diluted river water samples that spiked with known $\mathrm{NH}_{4}{ }^{+}$ion concentrations in the range of $0.17-1.02 \mathrm{mg} / \mathrm{L}$. Table 4 shows the results of the performance of biosensor response against different river water samples spiked with known $\mathrm{NH}_{4}{ }^{+}$ion concentration. The average recovery values obtained were close to $100 \%$ within experimental error. Thus, $\mathrm{NH}_{4}{ }^{+}$biosensor developed in this study has been validated with the standard method of Nessler method. The large variations in the standard deviations observed between the spiked concentrations and the biosensor response in some samples, for example, sample 1 and 2 (Table 4), were most probably owing to the inconsistency in the spiking technique used especially when lower concentrations of ammonium ion is involved.

To ensure whether the analytical results obtained by the proposed method give reliable results when used for quantitative determination of $\mathrm{NH}_{4}{ }^{+}$ion, river water samples with appropriate dilution were measured by both methods. Table 5 shows the results of the comparative study of the biosensor and Nessler method. The common $t$-test was
TABLE 5: The results of the comparative study of the AlaDH electrode and established Nessler method using different river water samples with appropriate dilution $(n=3)$

\begin{tabular}{llll}
\hline Sample & $\begin{array}{l}\text { Concentration of } \\
\mathrm{NH}_{4}{ }^{+} \text {ion by } \\
\text { biosensor }(\text { mean }), \\
\mathrm{mg} / \mathrm{L}(n=3)\end{array}$ & $\begin{array}{l}\text { Concentration of } \\
\mathrm{NH}_{4}{ }^{+} \text {ion by } \\
\text { Nessler method } \\
\text { (mean), mg/L } \\
(n=3)\end{array}$ & $t$ value \\
\hline Sample 1 & $0.88 \pm 0.11$ & $0.73 \pm 0.04$ & 2.179 \\
Sample 2 & $0.77 \pm 0.07$ & $0.62 \pm 0.07$ & 2.509 \\
Sample 3 & $0.78 \pm 0.11$ & $0.94 \pm 0.12$ & 1.688 \\
Sample 4 & $0.73 \pm 0.26$ & $0.67 \pm 0.02$ & 0.407 \\
Sample 5 & $0.77 \pm 0.21$ & $0.77 \pm 0.08$ & 0.039 \\
\hline
\end{tabular}

applied to examine whether the two methods give results that differed significantly at 95\% confident level.

The results showed that the calculated $t$-test values were less than the $t$ critical value of 2.776 with 4 degrees of freedom. The result shows that both methods have no statistically significant difference for $\mathrm{NH}_{4}{ }^{+}$ion determination. This may be due to the lack of interferences from impurities in the real sample against the developed biosensor. This indicates that the results from both methods are comparable.

\section{Conclusion}

The optimised AlaDH enzyme-based electrode was found useful for the sensitive measurement of $\mathrm{NH}_{4}{ }^{+}$ion. In addition, the reproducibility and repeatability of measurements of the electrode was reasonable. The preparation of AlaDH enzyme-containing membrane on SPE involved simple photolithography technique. This may be considered disposable as the fabrication method allows mass production at low cost. The electrode exhibited a high sensitivity (LOD, $8.52 \mu \mathrm{g} / \mathrm{L}$ ) and a dynamic range between $0.03-1.02 \mathrm{mg} / \mathrm{L}$. A good agreement between the biosensor and Nessler method demonstrated the high practically and accuracy of the biosensor in the analysis of water samples.

\section{Acknowledgments}

The authors would like to acknowledge Research University Operation Fund provided by Universiti Kebangsaan Malaysia (UKM-OUP-NBT-29-151/2011). The authors would also like to thank Universiti Kebangsaan Malaysia for a Postgraduate Fellowship awarded to Tan Ling Ling.

\section{References}

[1] A. K. Abass, J. P. Hart, D. C. Cowell, and A. Chappell, "Development of an amperometric assay for $\mathrm{NH}_{4}{ }^{+}$based on a chemically modified screen-printed NADH sensor," Analytica Chimica Acta, vol. 373, no. 1, pp. 1-8, 1998.

[2] K. T. Lau, S. Edwards, and D. Diamond, "Solid-state ammonia sensor based on Berthelot's reaction," Sensors and Actuators B, vol. 98, no. 1, pp. 12-17, 2004.

[3] P. Q. Li, J. Z. Zhang, F. J. Millero, and D. A. Hansell, "Continuous colorimetric determination of trace ammonium 
in seawater with a long-path liquid waveguide capillary cell," Marine Chemistry, vol. 96, no. 1-2, pp. 73-85, 2005.

[4] K. Waich, T. Mayr, and I. Klimant, "Fluorescence sensors for trace monitoring of dissolved ammonia," Talanta, vol. 77, no. 1, pp. 66-72, 2008.

[5] S. Zougar, K. Morakchi, K. Zazoua, S. Saad, R. Kherrat, and N. J. Renault, "Characterization of ammonium ion-sensitive membranes in solution with electrochemical impedance spectroscopy," Materials Science and Engineering C, vol. 28, no. 5-6, pp. 1020-1023, 2008.

[6] N. L. J. Wee, Y. Y. M. Tng, H. T. Cheng, S. M. L. Lee, S. F. Chew, and Y. K. Ip, "Ammonia toxicity and tolerance in the brain of the African sharptooth catfish, Clarias gariepinus," Aquatic Toxicology, vol. 82, no. 3, pp. 204-213, 2007.

[7] P. Y. Wang, J. Y. Wu, H. J. Chen, T. Y. Lin, and C. H. Wu, "Purge-and-trap ion chromatography for the determination of trace ammonium ion in high-salinity water samples," Journal of Chromatography A, vol. 1188, no. 2, pp. 69-74, 2008.

[8] S. T. Dubas and V. Pimpan, "Green synthesis of silver nanoparticles for ammonia sensing," Talanta, vol. 76, no. 1, pp. 29-33, 2008.

[9] R. C. H. Kwan, P. Y. T. Hon, and R. Renneberg, "Amperometric determination of ammonium with bienzyme/poly(carbamoyl) sulfonate hydrogel-based biosensor," Sensors and Actuators B, vol. 107, no. 2, pp. 616-622, 2005.

[10] B. Pranaityte, S. Jermak, E. Naujalis, and A. Padarauskas, "Capillary electrophoretic determination of ammonia using headspace single-drop microextraction," Microchemical Journal, vol. 86, no. 1, pp. 48-52, 2007.

[11] P. Marcaggi and J. A. Coles, "Ammonium in nervous tissue: transport across cell membranes, fluxes from neurons to glial cells, and role is signalling," Progress in Neurobiology, vol. 64, no. 2, pp. 157-183, 2001.

[12] R. Liu, B. Sun, D. Liu, and A. Sun, "Flow injection gasdiffusion amperometric determination of trace amounts of ammonium ions with a cupric hexacyanoferrate," Talanta, vol. 43, no. 7, pp. 1049-1054, 1996.

[13] N. J. Renault, A. Senillou, C. Martelet, K. Wan, and J. M. Chovelon, "ISFET microsensors for the detection of pollutants in liquid media," Sensors and Actuators B, vol. 59, no. 2, pp. 154-164, 1999.

[14] M. Trinkel, W. Trettnak, F. Reininger, R. Benes, P. O’Leary, and O. S. Wolfbeis, "Study of the performance of an optochemical sensor for ammonia," Analytica Chimica Acta, vol. 320, no. 23, pp. 235-243, 1996.

[15] M. C. Icardo, I. G. Torro, L. L. Zamora, and J. M. Calatayud, "Flow spectrophotometric determination of ammonium ion," Analytica Chimica Acta, vol. 398, no. 2-3, pp. 311-318, 1999.

[16] H. Parham and M. Mobarakzadeh, "Solvent extractionSpectrophotometric determination of trace amounts of ammonium, barium and potassium in a mixture by dicyclohexyl-18-crown-6 and orange II," Talanta, vol. 58, no. 2, pp. 281-287, 2002.

[17] F. Deyhimi and B. G. Choobar, "Potentiometric determination of activity coefficients for $\mathrm{NH}_{4} \mathrm{Cl}$ in the ternary $\mathrm{NH}_{4} \mathrm{Cl} / \mathrm{LiCl} / \mathrm{H}_{2} \mathrm{O}$ mixed electrolyte system," Journal of Electroanalytical Chemistry, vol. 584, no. 2, pp. 141-146, 2005.

[18] S. S. M. Hassan, S. A. Marei, I. H. Badr, and H. A. Arida, "Novel solid-state ammonium ion potentiometric sensor based on zirconium titanium phosphate ion exchanger," Analytica Chimica Acta, vol. 427, no. 1, pp. 21-28, 2001.

[19] A. Aminot, R. Kerouel, and D. Birot, "A flow injectionfluorometric method for the determination of ammonium in fresh and saline waters with a view to in situ analyses," Water Research, vol. 35, no. 7, pp. 1777-1785, 2001.

[20] W. D. Boer, P. A. K. Gunnewiek, and H. J. Laanbroek, "Ammonium-oxidation at low $\mathrm{pH}$ by a chemolithotrophic bacterium belonging to the genus Nitrosospira," Soil Biology \& Biochemistry, vol. 27, no. 2, pp. 127-132, 1995.

[21] U. J. Strotmann and G. Windecker, "Kinetics of ammonium removal with suspended and immobilized nitrifying bacteria in different reactor systems," Chemosphere, vol. 35, no. 12, pp. 2939-2952, 1997.

[22] A. E. Taylor and P. J. Bottomley, "Nitrite production by Nitrosomonas europaea and Nitrosospira sp. AV in soils at different solution concentrations of ammonium," Soil Biology \& Biochemistry, vol. 38, no. 4, pp. 828-836, 2006.

[23] S. M. Oliveira, T. I. M. S. Lopes, I. V. Toth, and A. O. S. S. Rangel, "A multi-commuted flow injection system with a multi-channel propulsion unit placed before detection: spectrophotometric determination of ammonium," Analytica Chimica Acta, vol. 600, no. 1-2, pp. 29-34, 2007.

[24] C. T. Kuo, P. Y. Wang, and C. H. Wu, "Fluorometric determination of ammonium ion by ion chromatography using postcolumn derivatization with o-phthaldialdehyde," Journal of Chromatography A, vol. 1085, no. 1, pp. 91-97, 2005.

[25] Y. M. Martinez, R. H. Hernandez, and P. C. Falco, "Improved detection limit for ammonium/ammonia achieved by Berthelot's reaction by use of solid-phase extraction coupled to diffuse reflectance spectroscopy," Analytica Chimica Acta, vol. 534, no. 2, pp. 327-334, 2005.

[26] N. Kazanskaya, A. Kukhtin, M. Manenkova et al., "FETbased sensors with robust photosensitive polymer membranes for detection of ammonium ions and urea," Biosensors and Bioelectronics, vol. 11, no. 3, pp. 253-261, 1996.

[27] A. Senillou, N. J. Renault, C. Martelet, and F. Griffe, "A miniaturized ammonium sensor based on the integration of both ammonium and reference FETs in a single chip," Materials Science and Engineering C, vol. 6, no. 1, pp. 59-63, 1998.

[28] S. Yang, Z. Chen, Y. Li, X. Jiang, and X. Lin, "A novel reagentless biosensor based on self-assembled HRP and Nile Blue premixed with poly(styrenesulfonate) architectures," Canadian Journal of Analytical Sciences and Spectroscopy, vol. 51, no. 3, pp. 174-179, 2006.

[29] S. I. Kato, T. Ohshima, A. Galkin, L. Kulakova, T. Yoshimura, and N. Esaki, "Purification and characterization of alanine dehydrogenase from a marine bacterium, Vibrio proteolyticus," Journal of Molecular Catalysis B, vol. 23, no. 2-6, pp. 373-378, 2003.

[30] S. I. Hashimoto and R. Katsumata, "L-alanine fermentation by an alanine racemase-deficient mutant of the DL-alanine hyperproducing bacterium Arthrobacter oxydans HAP-1," Journal of Fermentation and Bioengineering, vol. 86, no. 4, pp. 385-390, 1998.

[31] I. Schroder, A. Vadas, E. Johnson, S. Lim, and H. G. Monbouquette, "A novel archeal alanine dehydrogenase homologous to ornithine cyclodeaminase and $\mu$-crystalin," The Journal of Bacteriology, vol. 186, no. 22, pp. 7680-7689, 2004.

[32] P. Bertocchi and D. Compagnone, "Amperometric ammonium ion and urea determination with enzyme-based probes," Biosensors and Bioelectronics, vol. 11, no. 1-2, pp. 1-10, 1996.

[33] T. Ohashima and K. Soda, "Purification and properties of alanine dehydrogenase from Bacillus sphaericus," European Journal of Biochemistry, vol. 100, no. 1, pp. 29-39, 1979.

[34] J. M. S. Renkema, H. Gruppen, and T. V. Vliet, "Influence of $\mathrm{pH}$ and ionic strength on heat-induced formation and 
rheological properties of soy protein gels in relation to denaturation and their protein compositions," Journal of Agricultural and Food Chemistry, vol. 50, no. 21, pp. 60646071, 2002.

[35] I. V. Curova, A. V. Cura, J. R. Volc et al., "Purification and partial characterization of alanine dehydrogenase from Streptomyces aureofaciens," Archives of Microbiology, vol. 150, no. 5, pp. 438-440, 2004.

[36] R. C. H. Kwan, P. Y. T. Hon, and R. Renneberg, "Amperometric biosensor for rapid determination of alanine," Analytica Chimica Acta, vol. 523, no. 1, pp. 81-88, 2004.

[37] Y. Arica and V. N. Hasirci, "Immobilization of glucose oxidase in poly(2-hydroxyethyl methacrylate) membranes," Biomaterials, vol. 8, no. 6, pp. 489-495, 1987.

[38] A. Isha, N. A. Yusof, A. Musa, D. Suhendra, W. M. Z. W. Yunus, and Z. Zainal, "A chemical sensor for trace V(V) ion determination based on fatty hydroxamic acid immobilized in polymethylmethacrylate," Sensors and Actuators B, vol. 114, no. 1, pp. 344-349, 2006.

[39] G. Bayramoglu, S. Akgol, A. Bulut, A. Denizli, and M. Y. Arica, "Covalent immobilisation of invertase onto a reactive film composed of 2-hydroxyethyl methacrylate and glycidyl methacrylate: properties and application in a continuous flow system," Biochemical Engineering Journal, vol. 14, no. 2, pp. 117-126, 2003.

[40] T. J. Bruno, Handbook of Basic Tables for Chemical Analysis, CPC Press, Paris, France, 2nd edition, 2004.

[41] R. Chang, Chemistry, McGraw-Hill, New York, NY, USA, 7th edition, 2002. 

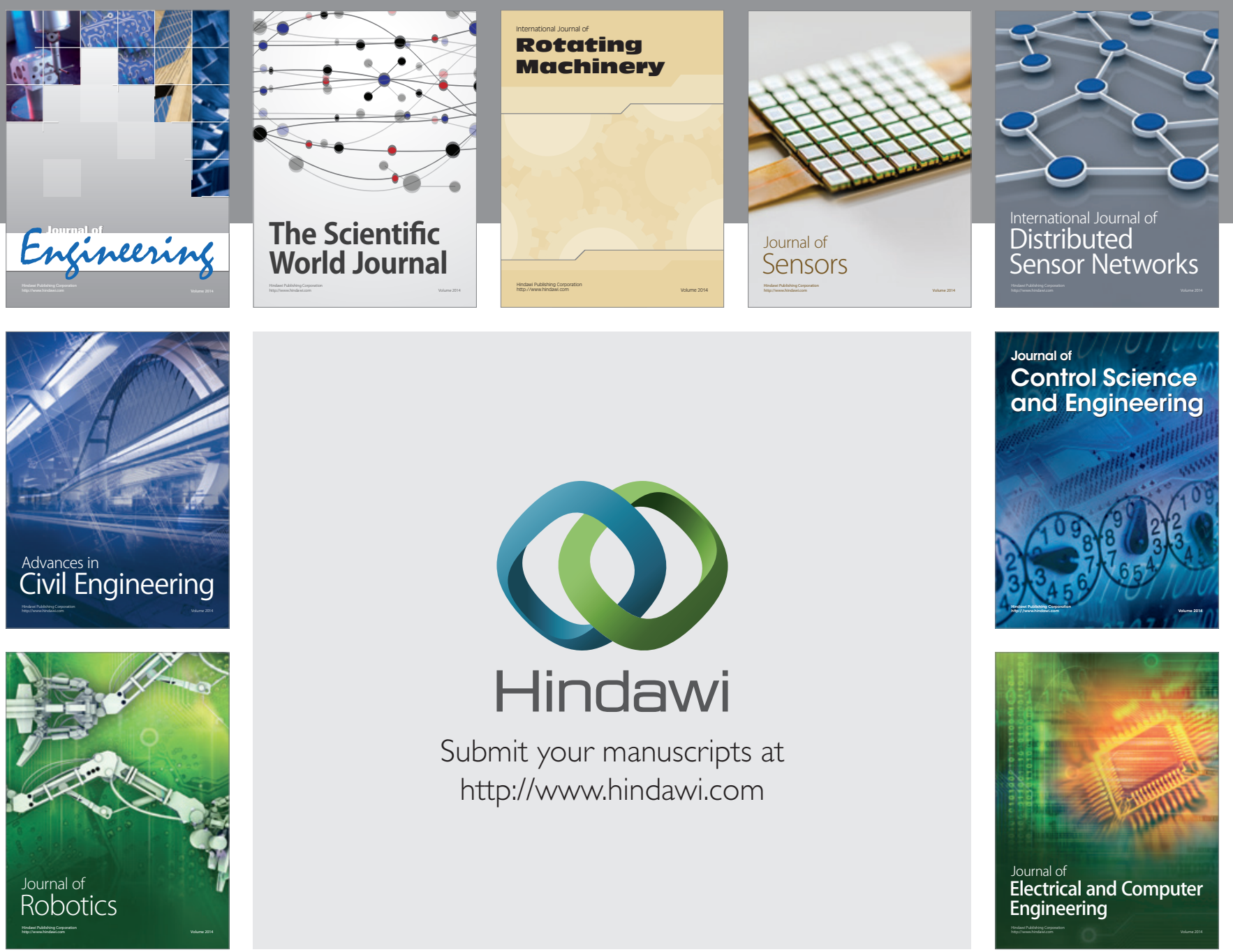

Submit your manuscripts at

http://www.hindawi.com
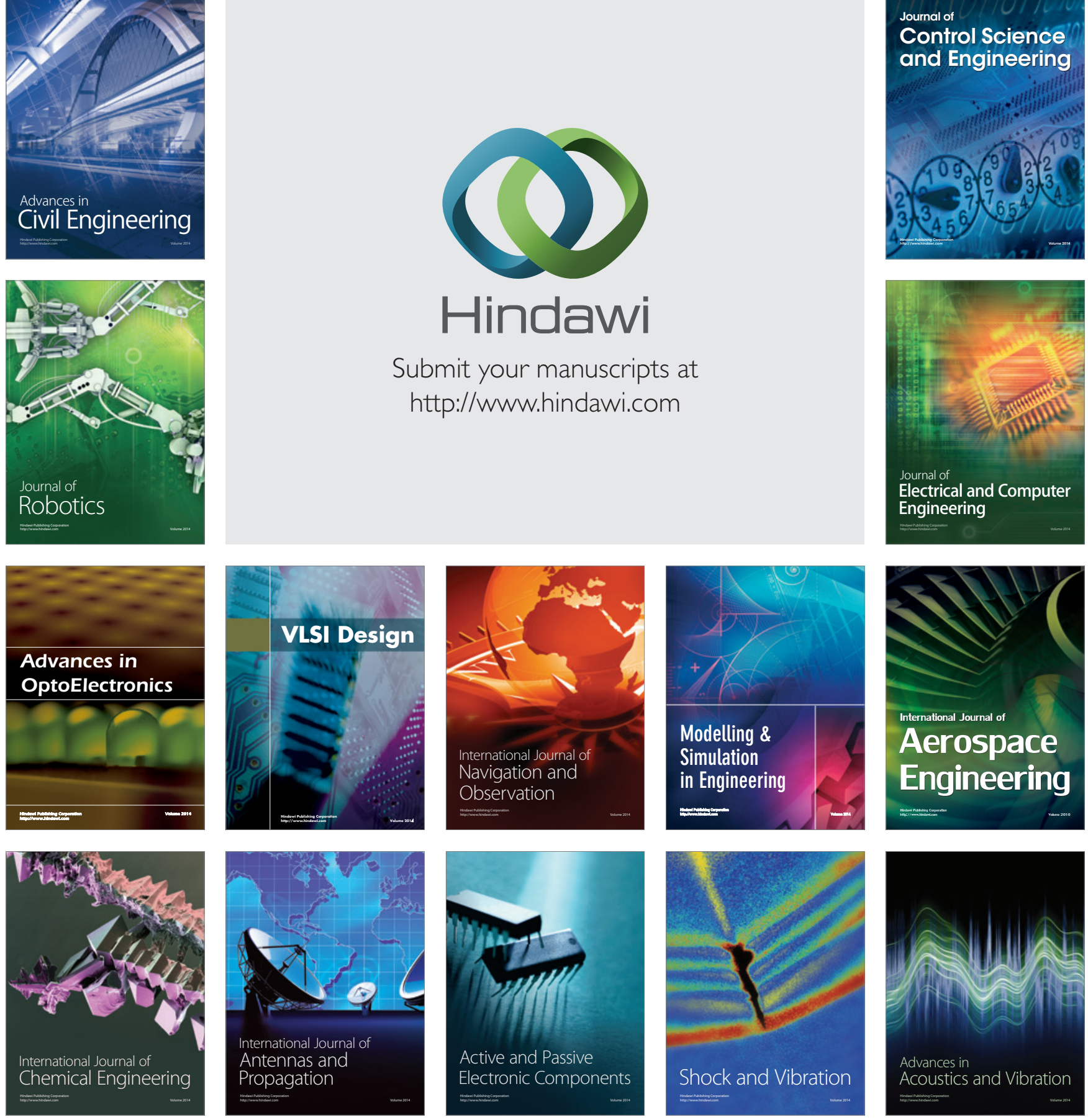